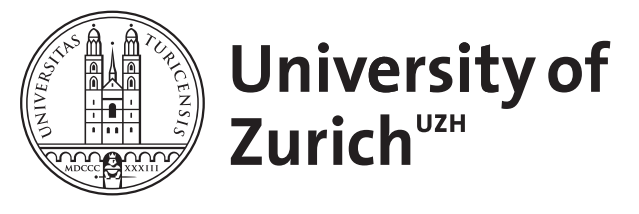

\title{
Stance in Fiction
}

\author{
Landert, Daniela
}

\begin{abstract}
This chapter deals with stance as the expression of evaluative, epistemic and affective attitudes. Stance is a multifaceted concept and it is used in different ways across different research traditions. In fiction, stance can be realised both in character speech and in narratorial voice, and it can be expressed verbally as well as through non-verbal means, such as gestures and facial expressions. Studying stance can provide insights into characterisation, the dynamics between characters, plot development and narrative perspective. The chapter provides an overview of the different ways in which stance is relevant for the study of fiction from a pragmatic perspective, and it points to the great potential of future research in this area.
\end{abstract}

DOI: https://doi.org/10.1515/9783110431094-016

Posted at the Zurich Open Repository and Archive, University of Zurich

ZORA URL: https://doi.org/10.5167/uzh-137441

Book Section

Published Version

Originally published at:

Landert, Daniela (2017). Stance in Fiction. In: Locher, Miriam A; Jucker, Andreas H. Pragmatics of Fiction. Berlin: De Gruyter, 489-514.

DOI: https://doi.org/10.1515/9783110431094-016 


\title{
16. Stance in fiction
}

\author{
Daniela Landert
}

\begin{abstract}
This chapter deals with stance as the expression of evaluative, epistemic and affective attitudes. Stance is a multifaceted concept and it is used in different ways across different research traditions. In fiction, stance can be realised both in character speech and in narratorial voice, and it can be expressed verbally as well as through non-verbal means, such as gestures and facial expressions. Studying stance can provide insights into characterisation, the dynamics between characters, plot development and narrative perspective. The chapter provides an overview of the different ways in which stance is relevant for the study of fiction from a pragmatic perspective, and it points to the great potential of future research in this area.
\end{abstract}

\section{Introduction}

Recent years have seen a growing interest in the linguistic study of how speakers and writers express stance. This includes the study of evaluative expressions, like beautiful, epistemic expressions, like possibly, and affective expressions, like I hate. Such stance expressions play an important role in fiction on different levels. On the level of the communication between narrator and addressee (or: the narratorial level), stance expressions can influence how a story is perceived, for instance when overt narrators explicitly evaluate characters and events. On the level of the communication between characters (or: the character level), stance expressions provide a resource for characterisation and character alignment. Characters can explicitly evaluate themselves and others and they can also be characterised more implicitly through their use of stance expressions, for instance as being insecure or determined.

Despite the relevance of stance for fiction, the amount of research that has explicitly been devoted to this area is limited. Linguistic studies of fiction have often discussed characteristics which are closely related to stance, but without focussing on stance itself. Examples include point of view, (im)politeness, speech acts, emotions, and characterisation (see also the relevant Chapters 4, 6, 14, 15 and 17 , this volume). On the other hand, work on stance has mostly focused on non-fictional language, especially conversation and academic writing. For instance, an influential volume in the area, edited by Hunston and Thompson (2000), contains contributions that focus on academic writing (Hoey 2000), conversational narratives (Cortazzi and Jin 2000), persuasive texts such as book reviews and comment 
articles from newspapers (Hunston 2000) and comparisons between academic writing, conversation, and news reportage (Conrad and Biber 2000). There is no contribution that is specifically devoted to fiction, although there are studies that are based on corpora which include fiction to a considerable extent (Channell 2000; Thompson and Zhou 2000). In addition, one of the papers (Martin 2000) uses many examples from a play, Educating Rita by Willy Russell, as illustrations of dialogue, without discussing the status of the play as a fictional text. Instead, the examples appear alongside examples from newspapers, magazines and classroom writing and, collectively, these contexts are taken to represent language use more generally. This treatment of fiction in Hunston and Thompson's volume is quite typical of the treatment of fiction in research on stance more generally.

The aim of this chapter is not so much to provide a comprehensive overview of exisiting research on stance in fiction, but to point out some of the aspects in which stance is relevant for the study of the pragmatics of fiction, as well as to indicate some of the research traditions in which related work has been carried out. I will start by giving a very brief introduction into classifications of stance expressions and related concepts in Section 2. In Section 3, I will introduce corpus studies as one line of research in which stance has been investigated in fictional data, in particular approaches that compare stance expressions across different registers. While these studies often do not devote a great deal of attention to the status of the data as fiction, the remaining sections all deal with aspects of stance that are intrinsically related to the nature of fiction. Section 4 discusses the role of stance on the narratorial level, in particular its relevance for narrative perspective and narratorial voice. Section 5 looks at stance expressions in character dialogue and explores the link between stance taking and character alignment. In Section 6, finally, I will connect some of the latest developments in research on stance and in research on the pragmatics of fiction by looking at multimodal stance in telecinematic discourse.

\section{Types of stance}

Stance expressions cover a wide variety of different attitudes, which are often classified into several groups according to the kind of attitude that is expressed (see also Keisanen and Kärkkäinen 2014: 297). Evaluative stance refers to assessments that, in most general terms, fall somewhere along a continuum from good to bad. This includes value judgements that express how desirable, aesthetic, correct or appropriate something is. Adjectives such as good, inferior, beautiful, and wrong are a common way of expressing evaluative stance. Affective stance expresses emotions, for instance with verbs like love, adjectives like happy and adverbs like sadly. Epistemic stance deals with the degree of certainty or reliability of information. Expressions such as I am sure and certainly are used to communicate a high 
degree of certainty, whereas I doubt and possibly mark information as being less certain. Epistemic stance is closely related to evidentiality, which is the indication of the source of information. In languages like English, which lack morphological marking of epistemicity and evidentiality, stance expressions often combine information about both aspects. For instance, I believe expresses a strong commitment to the reliability of information (epistemicity) and it also marks information as being based on the speaker's or writer's own belief (evidentiality). In contrast, apparently expresses a lower degree of certainty and it indicates that the speaker or writer has some form of external evidence. The last group of stance meaning is style of speaking stance, which is used to characterise the ongoing communication. Examples are frankly, to be honest, strictly speaking, and I swear (see Biber et al. 1999: 975).

There is no general agreement among researchers as to which subtypes ought to be included in studies of stance and how exactly to draw the lines between different types of stance. For instance, in the Longman Grammar of Spoken and Written English, Biber et al. (1999) distinguish three types of stance, namely epistemic stance (which includes evidential stance), attitudinal stance (which covers both evaluative and affective stance), and style of speaking stance. This last type, style of speaking stance, is rarely treated as a separate category by other scholars.

In addition, terminology varies greatly across approaches. Some approaches use evaluation as a cover term under which other types of stance are subsumed (e.g. Bednarek 2006; Thompson and Hunston 2000), while for others, evaluative stance is one subcategory of stance (e.g. Kärkkäinen 2003; Keisanen and Kärkkäinen 2014). Some scholars see a functional difference between the two concepts. For instance, Du Bois (2007: 163) defines stance as a "public act" that is achieved through "simultaneously evaluating objects, positioning subjects (self and others), and aligning with other subjects". Thus, according to his definition, evaluation is one of three components that together establish a stance. Alba-Juez and Thompson (2014: 10) draw the distinction between stance and evaluation in a different way, defining evaluation as the "expression of the speaker's stance or attitude" (emphasis in original). In other words, they see stance as "a more abstract concept" and evaluation as the realisation of stance through communication (Alba-Juez and Thompson 2014: 10). Others adopt an entirely different classification system for the meanings introduced above, such as the Appraisal Framework that was developed in the tradition of Systemic Functional Linguistics (Martin 2000; Martin and White 2005). The framework distinguishes three different types of stance meanings: affect, which is similar to affective stance introduced above; judgement, which covers moral evaluations; and appreciation, which refers to other types of evaluations, such as evaluations of aesthetic quality. Moreover, there are a number of research areas and topics that overlap with the study of stance and stance expressions to a considerable extent, including, for instance, (inter-)subjectivity, modality, pragmatic markers, emotional language, vague language, intensifiers 
and hedges. It is not possible to discuss the relation between each of these concepts and stance here (but see, for instance, Englebretson 2007; Jaffe 2009; Keisanen and Kärkkäinen 2014; Thompson and Hunston 2000).

There is a wide range of linguistic resources that can be used to express stance. Lexical items that tend to express stance meanings can include adjectives, verbs, nouns and adverbs. Certain structural patterns have also been identified as playing an important role for stance marking. These include sentence adverbials, thatand to-complement clauses, nouns followed by prepositional phrases, and modal verbs (Biber et al. 1999: 969-970; Gray and Biber 2014). In addition, some languages have morphological markers of stance. Alba-Juez and Thompson (2014: 100) present examples from Spanish, where the use of the suffixes -ucho/a, uco/a, and -azo/a can turn adjectives and nouns into negatively evaluated nouns (e.g. larguirucho 'a tall but graceless person', from largo 'long/tall' + -ucho). Examples of morphological markers of evidentiality can be found in Cuzco Quechua, where enclitics indicate whether the information expressed in the verb is based on the speaker's own observation, on information reported by someone else, or on conjecture (Faller 2002: 3; see also Aikhenvald 2004).

Apart from these explicit markers, stance can also be expressed more implicitly. Biber et al. (1999) mention non-linguistic and paralinguistic means of stance marking. Non-linguistic means include gestures, facial expressions, and body postures, while paralinguistic means refer to pitch, intensity and duration (Biber et al. 1999: 697). Alba-Juez and Thompson (2014: 100) point out that an utterance such as I'm sure he cares for you can express a positive or negative (e.g. ironic) evaluation, depending on intonation and context (see also Escandell-Vidal, Marrero Aguiar, and Pérez Ocón 2014; Estebas-Vilaplana 2014). It is clear that these are characteristics that are especially relevant for the study of spoken language, but similar effects can be achieved in written language, for instance through the use of special fonts, formatting (large font or boldface), capitalisation, emoticons and emojis. Finally, in both written and spoken language, context plays an important role when expressing and interpreting stance. Given that there is no one-to-one relation between linguistic forms and stance meanings, it is often the context that allows interactants to decide whether a stance is expressed or not. In addition, there are cases in which stance is expressed without any clear conventional stance markers, so that it is difficult to pinpoint lexical items or linguistic structures that create the stance meaning. Hunston (2004) demonstrates this point with the following example:

(1) The intention of this article is not to offer 'new ideas' for pedagogical application, but to share a very real concern about our survival both as teachers and as human beings. If this seems unduly dramatic, then so be it. Our situation is already dramatic almost to the point of tragedy. We are at risk - from the pressures of consumerism, the media, technology, and rampant trivialisation. Our lives are lived at an increasingly accelerating pace, leaving less and less time for mature reflection and the exercise of independent 
choice. The results are burnout, breakdown and a loss of the ability to direct our own lives. We risk becoming units in the service of a system we no longer understand, rather than the vibrant individuals we are all capable of being. (Maley 1999, presented and discussed in Hunston 2004: 159)

Hunston (2004: 159) argues that this passage "sets up a value system in which some entities are 'good', others are 'bad'". In a later publication, Hunston (2007: 39) further points out that it is questionable whether stance is created exclusively through linguistic means in this passage. While there are lexical items that express a negative attitude (e.g. tragedy, risk), more general cultural evaluations of how time is spent also seem to play an important role. Thus, context has to be taken into account for the study of stance.

Traditionally, most studies of stance and related notions have focused on explicit stance markers. However, recently there has been an increasing focus on stance in interaction, where stance is expressed in dialogic settings and often in more implicit ways (for a recent overview of research on stance in interaction, see Keisanen and Kärkkäinen 2014). This line of research investigates how speakers position themselves in relation to their interlocutors through stance taking. Speakers can create different degrees of alignment with other participants by either sharing their stance or by taking a different stance. In this way, stance taking becomes an important resource for establishing participant roles in interaction and, accordingly, Du Bois (2007: 139) refers to stance as "a linguistically articulated form of social action". Going one step further still, Bucholtz and Hall (2005) link stance taking to identity construction. They see identity as a product that is constructed through linguistic practices in interaction. Building on the view of stance as social action, they argue that over time stances can "accumulate into more durable structures of identity" (Bucholtz and Hall 2005: 596).

From this very brief overview it should have become clear that stance is a multifaceted concept that is used in different ways across different research traditions. More grammatically oriented approaches adopt a narrow definition in which stance refers to the speaker's or writer's subjectivity in the form of personal attitudes and judgements. According to this view, stance is a local phenomenon that can be tied to specific lexico-grammatical patterns. In contrast, interactional approaches use a broader definition in which stance is linked to social positioning and identity construction. These latter approaches tend to focus on the intersubjective construction of stance, in which stance is not restricted to specific lexical forms or grammatical patterns.

As a consequence of the different uses of the term, the concept of stance will slightly change across the sections that follow. The corpus approaches described in Section 3 tend to focus on stance expressions that are realised in fixed lexico-grammatical patterns and, thus, can be identified automatically. In contrast, implicit and interactional stance expressions become more important for topics covered in later parts of this chapter, especially for the discussion of multimodal stance. 


\section{Corpus approaches to stance}

Some studies of stance are based on data that include fiction, even though the specific relation between stance and fiction is not explored in detail. Instead, fiction is treated as one type of data alongside other data that represent language use more generally and thus can be used to study specific linguistic phenomena, such as stance. This is especially true for corpus approaches to the study of stance, given that most corpora that attempt to represent language use overall contain a substantial amount of text from fiction. For instance, fiction contributes $20 \%$ of data to the 450 million word Corpus of Contemporary American English (Davies 2012), $19 \%$ to the written part of the British National Corpus (Burnard 2009) and 12\% to the Longman Grammar of Spoken and Written English corpus (Biber et al. 1999: 25). There are various reasons why fiction is so well represented in corpora. One reason is that it is a reflection of how language is used. The amount of language produced as part of fictional texts is huge and many of us devote a great deal of time to reading and watching fiction, both in educational settings and for recreational purposes. Some forms of fiction are further seen as instances of especially artistic, aesthetic and exemplary realisations of language, such as the works of Shakespeare and other canonical authors. Finally, fictional texts - especially those whose copyright has expired - are comparatively easy for researchers to access. Printed books do not need to be transcribed, unlike conversations; access to novels and plays is easier than access to private correspondence; and books - fictional and non-fictional - are increasingly available in digital form.

Corpus-based studies of stance can be divided into several groups. Research in the first group is interested in language use overall and no comparison is made between stance in fiction and stance in other registers. Hunston's $(2007,2011)$ work on evaluative stance belongs to this category. Based on the Bank of English Corpus, she studies expressions and phraseologies that express evaluative stance. She interprets examples in the context of the concordance lines in which they occur and she is able to show that the phrases in which evaluative lexical items are used and other co-occurring expressions play a role for the stance that is expressed. Since the Bank of English Corpus includes data from fiction, her examples are partly based on fiction. However, there is no detailed analysis of how different registers influence or condition stance expressions, or how stance expressions can serve specific functions in specific registers. Thus, such approaches reveal new insights into stance expressions in general, but they do not throw much light onto the more specific role stance expressions play in fiction. Still, the fact that fictional data is very well represented in many corpora means that it is likely to influence findings that are based on these corpora. This makes it all the more important to study the specific ways in which stance is used in fiction in more detail.

The second group of corpus-based studies deals with differences in stance across different sections of corpora, for instance differences between fiction, aca- 
demic writing, news writing and conversation. The focus mainly lies on quantitative differences between registers, and not all of the studies include fiction. For instance, Conrad and Biber (2000) and Gray and Biber (2014) restrict their analysis to three registers, academic writing, news and conversation. In other cases, fiction is included but stance is not the focus of the study, for instance in Bednarek's (2008) cross-register comparison of emotional language. Still, there are some findings in this line of research that are relevant for stance in fiction. Biber et al. (1999: 979) are able to show that stance markers are more frequent in fiction than in other written registers (news and academic writing), but less frequent than in conversation. According to them, one factor that contributes to the higher frequency in fiction compared to other written registers is the fact that fiction often contains reported speech, as well as representations of the private thoughts of characters (Biber et al. 1999: 980). Such results can provide some insights into more specific aspects of stance in fiction. They indicate, for instance, that dialogues between characters are one of the places in which stance markers are likely to be found. In addition, if the representation of characters' private thoughts is an area where stance features prominently, this suggests that the particular type of narrative perspective used will have a marked influence on how stance is expressed. These two aspects are explored in further detail in Sections 4 and 5 below.

The last group of corpus-based studies that is of relevance to stance in fiction includes research that investigates the similarities between fictional dialogues and spontaneous face-to-face conversation. Most of these studies do not have an exclusive focus on stance, but since stance markers are one of the characteristics that indicate linguistic immediacy and spontaneity, they often play a central role. Quaglio (2009) presents a multidimensional corpus study in which he compares dialogues from the television series Friends to data from face-to-face conversations. His findings suggest that the two sets of data share many similarities. As far as stance markers are concerned, Quaglio's discussion of vague language and emotional language includes some epistemic stance markers, but they do not show a very clear picture. While probably is less frequent in Friends than in conversation, maybe, perhaps and of course are more frequent in television dialogue (Quaglio 2009: 82-83, 95). Tagliamonte and Roberts (2005) study intensifiers in Friends and conclude that the data show almost the same rate of intensification as contemporary spoken English. In contrast, Bednarek (2010: 78) analyses data from the television series Gilmore Girls and finds that stance-related n-grams like I think and I mean are under-represented compared to face-to-face conversation. 


\section{Stance and narratorial voice}

As mentioned earlier, one place in which stance expressions occur in fiction is in the narrator's voice. A stance expressed by the narrator is part of the communication between the fictional text and the reader and evaluations and assessments of characters and events influence the reader's perception of the story. Different classifications of narrators and narratorial voice have been proposed (e.g. Fowler 1996; Simpson 1993; Toolan 1988; for a brief overview, see, for instance, Leech and Short 2007: 206-218; Neary 2014; Niederhoff 2009); they will not be discussed here in detail (but see Messerli, Ch. 2, this volume and Hoffmann, Ch. 6, this volume). However, it is important to note that there seem to be systematic relations between the type of narration and the use and effects of stance markers, and it has been pointed out that stance markers play an important role for establishing narrative voice (Simpson 1993: Ch. 3; see also Bednarek 2008: 186; Martin and White 2005: 72). One aspect that is very clearly tied to stance marking is the degree of perceptibility, i.e. whether narrators are overt, having a strong presence in the text, or covert, having very little presence in the text (Rimmon-Kenan 2002: 97-101). Overt narrators express their stance more clearly than covert narrators, who tend to present descriptive accounts with very little narratorial intervention.

Ernest Hemingway is often quoted as an example of an author whose writing typically features covert narrators.

(2) Francis Macomber had, half an hour before, been carried to his tent from the edge of the camp in triumph on the arms and shoulders of the cook, the personal boys, the skinner and the porters. The gun-bearers had taken no part in the demonstration. When the native boys put him down at the door of his tent, he had shaken all their hands, received their congratulations, and then gone into the tent and sat on the bed until his wife came in. She did not speak to him when she came in and he left the tent at once to wash his face and hands in the portable wash basin outside and go over to the dining tent to sit in a comfortable canvas chair in the breeze and the shade. (Hemingway [1936] 1962: 11, "The Short Happy Life of Francis Macomber")

In this extract from the short story "The Short Happy Life of Francis Macomber", there are no explicit stance markers that evaluate the events or the characters. There are a few lexical items that carry an evaluative meaning, such as triumph and congratulations, which indicate that something positive took place. Apart from that the narratorial account consists of a series of factual statements, and it does not even become clear whether the narrator shares the positive evaluation of the event that is celebrated as triumph. The lack of overt stance markers means that the narrator remains in the background and indeed the absence of stance in narratorial voice is one of the defining features of a covert narrator.

There are different types of overt narrators and for each of these types, the effect of stance expressions on the communication between text and reader is slightly different. Extradiegetic third-person narrators are narrators that do not 
take part in the narrated events and who also do not refer to themselves in the first person. The narrator in Hemingway's short story is an extradiegetic third-person narrator, but not all narrators of this type are as covert as Hemingway's. In Jane Austen's Emma, for instance, we can find an extradiegetic third-person narrator who presents explicit evaluations of events and characters.

(3) Emma Woodhouse, handsome, clever, and rich, with a comfortable home and happy disposition, seemed to unite some of the best blessings of existence; and had lived nearly twenty-one years in the world with very little to distress or vex her. [...] The real evils indeed of Emma's situation were the power of having rather too much her own way, and a disposition to think a little too well of herself; these were the disadvantages which threatened alloy to her many enjoyments. The danger, however, was at present so unperceived, that they did not by any means rank as misfortunes with her. (Austen [1816] 2003: 5, Emma)

This opening passage of the novel contains evaluative lexical items that characterise the protagonist as handsome, clever, and rich. The epistemic marker seemed introduces an element of uncertainty with respect to this positive characterisation. In the second part of the quoted passage, the narrator proceeds to present Emma's disadvantages and the real evils of her situation. Finally, the narrator also presents Emma's own evaluation of herself, stating that the danger described by the narrator was unperceived by the protagonist. The fact that Emma's evaluation does not agree with the narrator's evaluation creates a certain distance between the reader and the protagonist, which is an important factor contributing to the irony for which the novel's style is known.

George Eliot's novels include examples of extradiegetic narrators who occasionally use the first person, which makes them even more overt. Some of these passages express an attitude towards the described events, such as regret at the beginning of Chapter 24 of Middlemarch.

(4) I am sorry to say that only the third day after the propitious events at Houndsley Fred Vincy had fallen into worse spirits than he had known in his life before. (Eliot [18711872] 1965: 273, Middlemarch)

In other cases, the evaluation extends to characters and to more general social norms. Often, Eliot combines the use of explicit stance markers with rhetorical questions, and sometimes her narrator even addresses readers directly (see also Leech and Short 2007: 214).

(5) Instead of wondering at this result of misery in Mr Casaubon, I think it quite ordinary. Will not a tiny speck very close to our vision blot out the glory of the world, and leave only a margin by which we see the blot? (Eliot [1871-1872] 1965: 456, Middlemarch, also quoted in Leech and Short 2007: 214) 
(6) If you blame Mr. Riley very severely for giving a recommendation on such slight grounds, I must say you are rather hard upon him. (Eliot [1880] 1985: 30, The Mill on the Floss)

The use of rhetorical questions and direct address invites readers to evaluate the events and characters and to share the stance of the narrator. This is especially clear in Example (6) from The Mill on the Floss, in which the narrator explicitly evaluates a potential stance of the reader.

The last group of overt narrators that I would like to discuss briefly are first-person character narrators. These are narrators who tell a story in which they participate themselves. There are different subtypes, depending on the centrality of the character in the story and the temporal perspective from which the story is told. I will discuss only one case, namely the narrator in Dickens' Great Expectations. Pip is a first-person character narrator who looks back on his own life and, in doing so, evaluates himself and his past actions.

(7) I am afraid I was ashamed of the dear good fellow, - I know - I was ashamed of him, when I saw that Estella stood at the back of Miss Havisham's chair, and that her eyes laughed mischievously. (Dickens [1860-1861] 2000: 83, Great Expectations, emphasis in original)

There are two different levels of stance present in this passage. On the one hand, the young Pip, who is the focaliser of this passage, is ashamed of Joe, his brother in law, which implies a negative evaluation of Joe, who is not behaving according to the expected social norms. On the other hand, the older Pip, who is narrating the story, expresses his regret about his earlier feelings (I am afraid), describing Joe as a dear good fellow. The clash between these two different attitudes towards Joe reflects Pip's development throughout the novel.

\section{Stance in character dialogue}

While the previous section looked at stance in the narrator's voice, this section will deal with how characters express stance, and what kind of effect this creates. One way to approach this is to investigate explicit stance markers in character speech. Nørgaard (2014: 474) argues that epistemic stance markers in the speech of characters can be used for characterisation. For instance, if a character uses many markers of uncertainty, that character will appear less confident as a result. An example of such a characterisation can again be found in Hemingway's short story "The Short Happy Life of Francis Macomber". The story revolves around the fact that Francis Macomber is a coward, who, in the decisive moment of his big-game safari, is scared of shooting a lion. He is characterised as insecure and hesitant, and many of his turns consist of questions directed to Robert Wilson, the professional hunter who guides him and his wife on the safari. The dialogues in 
this short story do not contain many epistemic stance markers, but there are a few prominent instances in Macomber's turns that serve to reinforce his characterisation. The first of these appears at the beginning of the short story, in the second turn by Macomber:

(8) It was now lunch time and they were all sitting under the double green fly of the dining tent pretending that nothing had happened.

"Will you have lime juice or lemon squash?" Macomber asked.

"I'll have a gimlet," Robert Wilson told him.

"I'll have a gimlet too. I need something," Macomber's wife said.

"I suppose it's the thing to do," Macomber agreed.

(Hemingway [1936] 1962: 11, “The Short Happy Life of Francis Macomber”, emphasis added)

After hearing that both Wilson and his wife prefer a gimlet over lime juice or lemon squash, Macomber decides to follow their example. However, he uses "I suppose" as a hedge to express that he still has some reservations about their choice. This lets him appear hesitant and insecure, especially since he changes his mind despite not being entirely convinced. Three additional epistemic markers are used by Macomber slightly later in the story, again expressing uncertainty.

(9) "Women upset," said Wilson to the tall man. "Amounts to nothing. Strain on the nerves and one thing'n another."

"No," said Macomber. "I suppose that I rate for that for the rest of my life now."

"Nonsense. Let's have a spot of the giant killer," said Wilson.

"Forget the whole thing. Nothing to it anyway."

"We might try," said Macomber.

$[\ldots]$

"Maybe I can fix it on buffalo," he said. "We're after them next, aren't we?"

(Hemingway [1936] 1962: 13-15, “The Short Happy Life of Francis Macomber", emphasis added)

Even though there are not many epistemic stance markers used in Hemingway's short story overall, their strategic use has quite a distinct effect, contributing to Francis Macomber's characterisation as insecure and hesitant. The fact that the other characters tend not to use uncertainty markers creates a contrast that reinforces this characterisation.

That stance contributes to characterisation has also been shown for telecinematic discourse. In her analysis of the television series Gilmore Girls, Bednarek (2010) finds that there are marked differences between the key words and n-grams used by different characters. More precisely, the key words and n-grams indicate that some characters express certain types of stance (evaluative parameters in Bednarek's terminology) more frequently than others. She argues that this reflects different "scripted identit[ies]" of the characters, and refers to this aspect as "expressive character identity" (Bednarek 2010: 118). 
Another starting point for studying stance in character-character interaction is the body of research on stance in non-fictional interaction. Most of this research is dealing with face-to-face interaction and uses methods from conversation analysis to study stance taking (for a recent overview, see Keisanen and Kärkkäinen 2014). Obviously, there are a number of differences between face-to-face interaction and fictional dialogue. While the former is typically taking place spontaneously the latter is carefully constructed (Culpeper and Kytö 2010: 67; see also Bublitz, Ch. 8, this volume, on features of orality). Fictional dialogues are usually realised in the written mode - even though in the case of plays and telecinematic discourse they may be intended to be spoken - and they differ from face-to-face interaction with respect to the purposes they serve. Still, based on the fact that fictional dialogues are meant to resemble spoken face-to-face interaction, it is possible to apply concepts from research on face-to-face interaction to fictional dialogues (see also Bednarek 2010, Ch. 5, this volume; Bubel 2011; Lambrou 2014; Quaglio 2009).

An important trend in the research on stance in face-to-face interaction is the shift in focus from stance markers in the speech of individuals to the collaborative construction of stance by several interacting participants (e.g. Du Bois 2007; Du Bois and Kärkkäinen 2012; Kärkkäinen 2006). Stance is thus seen as intersubjective rather than subjective, involving several participants who negotiate stance across several turns. Du Bois (2007) introduces the model of the stance triangle to capture different aspects of stance taking. He defines stance taking in the following way: "I evaluate something, and thereby position myself, and thereby align with you" (Du Bois 2007: 163). In other words, expressing an attitude positions the speaker in relation to other speakers, depending on the amount of agreement between their evaluations. A high degree of agreement results in convergent alignment whereas a low degree of agreement leads to divergent alignment. ${ }^{1}$ Du Bois further points out that convergent alignment is not only created through shared evaluations, but that speakers even take over formulations from previous speakers in order to align themselves with them. He develops a special notation, which he calls stance diagraph, that helps visualise these similarities (Table 1).

Du Bois avoids treating alignment and disalignment as a dichotomy. Instead, he sees alignment as a continuum that covers various degrees of convergent and divergent alignment. This point is perhaps best summarised in a footnote in Du Bois and Kärkkäinen (2012: 447): "What we call divergent alignment is often referred to as 'disalignment', a term we reject as dichotomizing. In contrast, alignment in our sense is analyzed as continuously variable. Degrees of divergent alignment, as well as of convergent alignment, are recognized." 
Table 1. Stance diagraph (Du Bois 2007: 166)

\begin{tabular}{|l|l|l|l|l|l|}
\hline$\#$ & Speaker & Stance Subject & Positions/ Evaluates & Stance Object & Aligns \\
\hline 1 & SAM & $\mathrm{I}_{1}$ & don't like & those & \\
\hline 3 & ANGELA & $\mathrm{I}_{2}$ & don't $\{$ like $\}$ & $\{$ those $\}$ & either \\
\hline
\end{tabular}

In Du Bois' example, Angela not only agrees with Sam with respect to her dislike, but she even adopts the same formulation he used two lines earlier, followed by either. By using the same formulation, her convergent alignment with Sam is reinforced. Similarities between turns can occur on different linguistic levels. Kärkkäinen (2006) finds a high degree of phonological, syntactic and/or semantic parallelism between different speakers in story telling. She concludes that similarities on different linguistic levels need to be taken into account when analysing how shared stances are negotiated.

Applied to fiction, the analysis of shared stances and linguistic alignment between characters can reveal insights into the dynamics between them. Again using Hemingway's short story "The Short Happy Life of Francis Macomber" as an example, we can see one instance of this in the first interaction between the three main characters of the story (see Example [8] above). Following Francis Macomber's question Will you have lime juice or lemon squash?, Robert Wilson and Macomber's wife Margaret both opt for a third alternative, a gimlet. Margaret Macomber's response I'll have a gimlet too takes over Wilson's formulation verbatim, which creates a very strong convergent alignment with Wilson and a divergent alignment with her husband. Thus, already in the first few lines of the story, the dynamics between the three main characters is expressed through a combination of explicit linguistic stance markers and the more implicit negotiation of shared stances.

In Hemingway's short story, the alignment between the characters is quite stable. In other cases, alignments can change over time, leading to different affiliations of characters over the course of a story. Bubel (2011) presents an analysis of the television series Sex and the City, in which she traces alignment patterns between the four protagonists of the series. She is able to show how shifts in alignments on the micro level - e.g. through the use of repetitions, discourse markers, shared laughter - lead to shifts in social relations on the macro level. For Sex and the City, she argues that two of the protagonists, Miranda and Carrie, have a stable relation as the "core friendship pair", while the other two friends, Charlotte and Samantha, are "more marginal members" whose status shifts over time (Bubel 2011: 247).

One aspect that makes fiction particularly interesting and challenging for the study of stance is that the two different levels on which stance occurs, the narrator's voice and the character's voice, can lead to layered stance expressions. The stance the narrator takes towards the character serves as a filter through which the 
audience perceives the character's stance (see also Culpeper and Fernandez-Quintanilla, Ch. 4, this volume, on narratorial filters). For instance, an expression of certainty by a character who is described as having poor judgement will be met with scepticism by the reader, as will a positive aesthetic evaluation by a character who is described as having bad taste. In these cases, the stance expressions by the character lead to a convergent alignment between audience and narrator and a divergent alignment between audience and character. The following passage from Emma can serve as an illustration. Emma here talks to Harriet after they met Mr. Martin, a farmer with whom Harriet is acquainted through frequent visits to his family. While Harriet likes Mr. Martin, Emma thinks that he is socially beneath Harriet.

(10) "I think, Harriet, since your acquaintance with us, you have been repeatedly in the company of some, such very real gentlemen, that you must yourself be struck with the difference in Mr. Martin. At Hartfield you have had very good specimens of well educated, well bred men. I should be surprized if, after seeing them, you could be in company with Mr. Martin again without perceiving him to be a very inferior creatureand rather wondering at yourself for having ever thought him at all agreeable before. Do not you begin to feel that now? Were not you struck? I am sure you must have been struck by his awkward look and abrupt manner-and the uncouthness of a voice, which I heard to be wholly unmodulated as I stood here." (Austen [1816] 2003: 26, Emma)

Emma presents a very negative evaluation of Mr. Martin, trying to convince Harriet that he is an unsuitable match for her. Despite the abundance of negative evaluative markers, the passage does not result in a construction of Mr. Martin's character as an "inferior creature". Instead, the fact that Emma was previously characterised as someone with questionable judgement and "the power of having rather too much her own way" (see Example [3] above) is likely to lead readers to reject, or at least question, this characterisation of Mr. Martin. At the same time the passage contributes to Emma's characterisation. Her words reveal her to be haughty and inconsiderate, in addition to being misguided in her judgement of $\mathrm{Mr}$. Martin. Thus, Emma's evaluation of Mr. Martin characterises Emma herself as much as it characterises him.

\section{Multimodal stance taking in telecinematic discourse}

So far, this chapter has discussed stance purely on the basis of written or spoken language. However, non-verbal aspects play an important role for expressing stance. Gestures, facial expressions, gaze, postures, distance, and spatial positioning can all contribute to or even create stance. For instance, a smile or a thumbs-up gesture can be used to express a positive evaluation, and an unsteady, evasive gaze can be used to express uncertainty or insecurity. As far as positioning is concerned, the concept was developed in the context of discursive psychology (Davies 
and Harré 1990) and it has been used to investigate how acts of positioning are realised through language (e.g. Bucholtz and Hall 2005; Du Bois 2007; Du Bois and Kärkkäinen 2012). However, the concepts of positioning and alignment are based on spatial metaphors and it is easy to see how they can also be realised through actual physical positioning and alignment with others in space. In written fiction, non-verbal aspects of characters' stance taking can be expressed verbally by the narrator. However, the interaction between spoken language and non-verbal cues of stance taking can best be analysed on the basis of telecinematic discourse, where non-verbal aspects are represented through images and sounds. (Recorded) theatre performances can be studied in a similar way, while comics and graphic novels provide a data source for studying visual cues of stance taking in combination with written language.

There has generally been a rise in research into multimodal discourse in recent years. As far as fiction is concerned, linguistic studies of telecinematic discourse have recently gained prominence (e.g. Androutsopoulos 2012; Bednarek 2010; Bleichenbacher 2008; Piazza, Bednarek, and Rossi 2011; Planchenault 2015), which is also evidenced by several of the chapters in this volume. Despite this recent interest, there is still very little research into the interaction between linguistic and non-verbal aspects of stance taking. Most of the findings on multimodal stance taking come from interactional linguistics, where video recordings of naturally-occurring interactions have been used as a data source. To give an example, Stivers (2008) studies how participants in storytelling align and affiliate themselves with the teller's stance through nodding. Keisanen and Kärkkeinen (2014: 308-313) present a brief overview of the body of work on stance taking in face-to-face interactions, as well as a case study that further illustrates how a multimodal analysis can enrich a purely text-based account.

In what follows, I will briefly point out some of the ways in which non-verbal aspects combine with the linguistic expression of stance in telecinematic discourse. Since this is a rather new research area, the main aim will be to identify promising avenues for future research.

For the discussion of stance in telecinematic discourse, like for written fictional texts, two different levels of communication need to be distinguished: the character level and the narratorial level. On the character level, non-verbal aspects of communication combine with the character's utterances in much the same way as they do in naturally-occurring interactions. Again, there are some obvious differences, similar to the differences between spontaneous conversation and fictional dialogues mentioned above. There are various factors that influence how closely non-verbal communication in telecinematic discourse mirrors that in spontaneous everyday interaction, including acting technique and genre (Bordwell and Thompson 2004: 199-207; Naremore 1988). Despite these differences, it is possible to apply methods from multi-modal conversation analysis to the analysis of telecinematic discourse in order to gain insights into embodied stance taking. 
There are two basic options how verbal and non-verbal communication can combine in stance taking. Either the non-verbal signals support the verbally expressed stance or they contradict it. Bednarek (2010: Ch. 7) finds both options in her detailed multi-modal analysis of a break-up scene between Max and Lorelai in the television series Gilmore Girls. For instance, Max provides a positive verbal evaluation of a kiss (That was a great kiss) and supports this evaluation with matching non-verbal behaviour, which Bednarek (2010: 154) describes as: "breathes out 'puh', shaking head very slightly [sort of 'unbelievably great']". In contrast, Lorelai's non-verbal behaviour contradicts her verbally expressed stance after Max breaks up with her. While agreeing with him verbally (Okay; Sure, that makes sense; No, you're right. You're absolutely right), her non-verbal behaviour indicates that she does not agree with the break-up (Bednarek 2010: 172). This can be seen, for instance, in her negative facial expression and restless hand movements, which express negative emotions (2010: 156). Bednarek interprets this contradiction as an attempt to be cooperative and harmonious and as possible reluctance to show emotion in the public setting of a coffee shop, which is where the break-up takes place (2010: 172). In this scene, verbal and non-verbal means combine to express a complex stance that can only be fully grasped by applying a multi-modal analysis.

On the narratorial level, camera perspective takes over some of the functions of explicit narratorial stance in written fictional texts (Naremore 1988: 39). In Müller's (2014: 34) words, "[t]he camera shapes the way in which viewers position themselves in relation to the storyworld and the way the storyworld emerges for them." Referring to F. W. Murnau's The Last Laugh (1924), she argues that the technique of the moving camera - which was an innovation at that time - allows viewers to share the characters' perspective and can even convey information about their thoughts that previously had to be provided by intertitles (2014: 33). From a linguistic perspective the central question is how camera perspective and other aspects can combine with explicit narratorial voice in order to express a narratorial stance that is comparable to that of overt narrators in written fiction. While explicit narratorial voice is less typical in telecinematic discourse than in written genres of fiction, it is still used occasionally in the form of voice-overs and asides to the audience (see Brown 2012; Hoffmann, Ch. 6, this volume).

In the remainder of this section, I will present a brief case study to illustrate how explicit narratorial voice can combine with different film and sound techniques to create narratorial stance. The scene I selected comes from the television series Mr. Robot (2015). The series describes the activities of a group of hackers who want to bring down a large multinational corporation by deleting all their financial records, at the same time liberating many citizens from their private debts. Elliot, the protagonist of the series, is suffering from anxiety disorder and morphine addiction and his unstable mental health soon becomes apparent to the viewer. Elliot is also the main focaliser of the story and sometimes he takes over 
the role of first-person narrator. In voice-overs he presents his thoughts and analyses ongoing events. The addressee of Elliot's narration is his imaginary friend, who is an effect of his mental health problems. The first episode of the series, entitled "eps1.0_hellofriend.mov", starts with a black screen (followed by credits) and Elliot's voice:

(11) Hello friend.

Hello friend?

That's lame.

Maybe I should give you a name.

But that's a slippery slope,

You're only in my head,

We have to remember that.

Shit.

It has actually happened.

I'm talking to an imaginary person.

(Mr. Robot 2015: Episode 1 "eps1.0_hellofriend.mov")

In later scenes, such uses of direct address are often accompanied by Elliot's gaze into the camera. There is a play between intradiegetic address of Elliot's imaginary friend as the addressee of his narration and extradiegetic address of the audience of the television series. The effect is that viewers feel addressed as Elliot's imaginary friend, which puts them in a problematic position as being part of his mental health problems. Elliot is an unusually overt narrator and his unstable mental health also means that he is an extremely unreliable narrator.

The next scene I analyse takes place towards the end of Episode 8. Elliot has just become aware of how serious his mental health problems are. In the previous scene, Darlene, another hacker in their group, told him that she is his sister, a fact that he had forgotten, apparently not for the first time. The scene describes his journey home and ends with the revelation that the leader of their group, Mr. Robot, does not exist. He is a product of Elliot's imagination, which he created based on his dead father.

Table 2 presents an overview of the scene. The first column gives time indications and the second column presents a rough transcription of Elliot's speech. All of the speech in this passage is in voice-over except for Were you? at 40:47 (in boldface), which is diegetic speech. The third column describes the visual track and sound effects that are relevant for the analysis. They form a second level of (extra-diegetic) narration in addition to Elliot's intra-diegetic narration. The scene spans only slightly more than one minute, but it is very dense and uses fast cutting, which makes it impossible to analyse each shot individually. It is also full of symbolism, which cannot be discussed here in detail. Instead, I will restrict my analysis to some salient aspects of how stance is created through the interplay of Elliot's words and filming techniques. 
Table 2. Description of scene from Mr. Robot 2015:

Episode 8 "eps1.7_wh1ter0se.m4v"

\begin{tabular}{|c|c|c|}
\hline Time & $\begin{array}{l}\text { Spoken monologue } \\
\text { (voice-over) }\end{array}$ & $\begin{array}{l}\text { Description of visual track and sound } \\
\text { effects }\end{array}$ \\
\hline $40: 21$ & $\begin{array}{l}\text { Darlene and I } \\
\text { would hide in movie theaters } \\
\text { all day. } \\
\text { Darlene would sing Frère } \\
\text { Jacques. } \\
\text { She rode her scooter in front of } \\
\text { our house. }\end{array}$ & $\begin{array}{l}\text { Elliot is shown, in a subway station com- } \\
\text { ing down a staircase to the platform. } \\
\text { This is followed by a series of very brief } \\
\text { medium-close to close-up shots of Elliot's } \\
\text { face from various directions (jump cuts) } \\
\text { while he is walking back and forth on the } \\
\text { platform. } \\
\text { The voice is changing direction of origin } \\
\text { with each intonation unit. }\end{array}$ \\
\hline $40: 27$ & $\begin{array}{l}\text { I'm crazy } \\
\text { I'm crazy } \\
\text { I'm crazy } \\
\text { I'm crazy } \\
\text { I'm crazy }\end{array}$ & Echo effect \\
\hline $40: 28$ & $\begin{array}{l}\text { She tried to run away in the } \\
\text { third grade. } \\
\text { How come I didn't remember } \\
\text { this? } \\
\text { We slept in the same bed when } \\
\text { our mom was mean to us. } \\
\text { Why did I forget? } \\
\text { I remember her voice. } \\
\text { How could I forget? }\end{array}$ & $\begin{array}{l}\text { Brief shots of Elliot walking down stair- } \\
\text { case (flashbacks) cut into shots of him } \\
\text { standing on platform (jump cuts) } \\
\text { The voice is changing direction of origin } \\
\text { with each intonation unit. }\end{array}$ \\
\hline $40: 36$ & $\begin{array}{l}\text { I'm crazy } \\
\text { I'm crazy } \\
\text { I'm crazy } \\
\text { I'm crazy } \\
\text { I'm crazy }\end{array}$ & $\begin{array}{l}\text { Echo effect } \\
\text { Entering subway (series of brief } \\
\text { non-chronological shots) } \\
\text { Close-up of Elliot facing camera, but not } \\
\text { quite looking into it }\end{array}$ \\
\hline $40: 39$ & $(2: 00)$ & \multirow{2}{*}{$\begin{array}{l}\text { Single shot } \\
\text { Elliot looks into the camera, face moving } \\
\text { slightly towards and away from camera, } \\
\text { as if trying to see properly. Elliot's face is } \\
\text { slightly out of focus, camera unsteady. }\end{array}$} \\
\hline $40: 41$ & $\begin{array}{l}\text { Are you freaking out? }(.) \\
\text { Tell me the truth. (.) } \\
\text { Were you in on this the whole } \\
\text { time? (.) }\end{array}$ & \\
\hline $40: 47$ & Were you? & $\begin{array}{l}\text { [still same shot] } \\
\text { Elliot shouting (only diegetic speech in this } \\
\text { sequence), directly addressing the viewer } \\
\text { while looking into the camera. }\end{array}$ \\
\hline
\end{tabular}




\begin{tabular}{|c|c|c|}
\hline Time & $\begin{array}{l}\text { Spoken monologue } \\
\text { (voice-over) }\end{array}$ & $\begin{array}{l}\text { Description of visual track and sound } \\
\text { effects }\end{array}$ \\
\hline $40: 48$ & $(2: 00)$ & $\begin{array}{l}\text { Camera angles downward, out of focus. } \\
\text { Black out, suggesting Elliot breaks camera. }\end{array}$ \\
\hline $40: 50$ & $\begin{array}{l}\text { Think, God damn it. } \\
\text { Think. } \\
\text { How can I just forget her like } \\
\text { that? } \\
\text { A whole person. } \\
\text { A relationship. } \\
\text { Is this amnesia? } \\
\text { What else am I not remember- } \\
\text { ing? } \\
\text { I'm crazy. } \\
\text { I should have stayed on the } \\
\text { meds. } \\
\text { I'm crazy. } \\
\text { I'm out of my mind. } \\
\text { I knew it, } \\
\text { I should have never created you. } \\
\text { I should have listened to Krista. }\end{array}$ & $\begin{array}{l}\text { Series of shots showing Elliot walking up } \\
\text { dark staircase in his house. } \\
\text { Entering his flat. }\end{array}$ \\
\hline $41: 05$ & $(5: 00)$ & \multirow[b]{2}{*}{$\begin{array}{l}\text { Long take of Elliot looking at himself in a } \\
\text { mirror, his face slowly approaching. } \\
\text { Shots of different faces approaching the } \\
\text { same mirror are cut in briefly (flash cuts). } \\
\text { One face wears a mask in the style of } \\
\text { Anonymous, the other face is Mr. Robot's. }\end{array}$} \\
\hline $41: 10$ & $\begin{array}{l}\text { I avoid myself. (.) } \\
\text { Why? (.) } \\
\text { I'm afraid. (.) } \\
\text { Okay. (.) } \\
\text { Afraid of what? (.) } \\
\text { Finding too much. (.) } \\
\text { Too little. } \\
\text { Nothing at all. } \\
\text { Do I even exist? (...) }\end{array}$ & \\
\hline $41: 24$ & $\begin{array}{l}\text { See me, (.) } \\
\text { Elliot Alderson. (.) } \\
\text { I am here. }\end{array}$ & $\begin{array}{l}\text { Camera zooms slightly out, still showing } \\
\text { Elliot looking at his reflection. }\end{array}$ \\
\hline $41: 28$ & $(4: 00)$ & $\begin{array}{l}\text { Elliot breaks mirror with his fist, shown } \\
\text { several times from different angles }\end{array}$ \\
\hline $41: 32$ & Now I'm gone. & $\begin{array}{l}\text { Elliot's face is shown in the remaining } \\
\text { shards of the broken mirror. }\end{array}$ \\
\hline
\end{tabular}


Clearly, the overall theme of this scene is Elliot's questioning of his own mental state and his identity, which implies his unreliability as a narrator. The passage contains several explicit verbal stance markers, the most prominent of which is his repeated evaluation of himself: I' $m$ crazy. More indirectly, by questioning his own memory, he adopts a stance of uncertainty towards the events that have been told so far. Both these aspects are supported in various ways through editing and sound effects. Starting with sound effects, the fact that Elliot's thoughts are presented in voice-over creates the impression that Elliot is "hearing voices". This is reinforced by the fact that at the beginning of the scene Elliot's voice is changing direction of origin with each intonation unit. For instance, Darlene would sing Frère Jacques appears to come from the left (from the point of view of the audience) while the following line, She rode her scooter in front of our house, appears to come from the right. This change of direction does not correlate with Elliot's position on the screen and therefore suggests that Elliot is not speaking or thinking with one coherent voice, but that his identity is unstable and fragmented. Another sound effect that contributes to this perception is the echo effect that is used with Elliot's statement I'm crazy. This line is realised in repeated overlapping versions, which again represents the dissolution of his stable identity. In combination, the sound effects support Elliot's explicit verbal evaluation of himself as crazy in various ways.

On the visual level, there are additional features that reinforce this stance. The scene makes repeated use of fast jump cuts, which are abrupt cuts in which the following shot does not match the previous shot seamlessly (Hayward 2006: 229). By disrupting space and time jump cuts can create a disorientation effect and they have been used by directors like Jean-Luc Godard and Alain Resnais to suggest instability and madness (Hayward 2006: 229). This is also the case here. For instance, at the beginning of the scene, there is a series of fast jump cuts showing Elliot's face from different perspectives. The pace and change of angle are too fast to present a natural change of perspective on the viewer's part, and neither does Elliot's movement on the subway platform seem natural. Instead, space and time appear disrupted and this enhances the sense of disorientation. Flashbacks are another editing technique that can be used to disrupt time. Between 40:28 and 40:36 Elliot is shown standing on the subway platform, but there are very brief flashbacks of him coming down the staircase ten seconds earlier, thus further adding to the disorienting effect of the jump cuts. The most meaningful use of jump cuts appears towards the end of the scene, when Elliot looks at himself in a mirror. Brief shots of two different faces are cut in. The first shows a face with a mask similar to those used by Anonymous. The second is the face of Mr. Robot, which suggests to the viewer that the character of Mr. Robot is not real, but part of Elliot's imagination.

In the middle of the scene (40:39-40:50), words, sound and image combine in a particularly powerful way. This is the sequence in which Elliot directly addresses 
the camera. On the linguistic level, direct address is realised with second person pronouns (you), questions (are you freaking out?) and imperatives (tell me the truth). This is supported visually by Elliot's gaze into the camera. On the level of sound, the question were you? is the only instance of diegetic speech in the entire scene, which gives special emphasis to Elliot's direct address. The fact that Elliot appears to hold and then break the camera once again blurs the boundaries between intradiegetic address of his imaginary friend and extradiegetic address of the viewer. The breaking down of the separation between the fictional world and the audience in this scene mirrors Elliot's inability to distinguish reality and imagination and thus conveys his unreliability.

In sum, the visual track and sound effects support Elliot's verbally expressed stance in different ways, leading to a rich, multimodal representation of stance. There are some aspects that are not expressed verbally, but that can only be perceived visually. Most importantly, Elliot never mentions Mr. Robot in this passage and the fact that he invented the character of Mr. Robot is only communicated by showing flashes of Mr. Robot's face instead of Elliot's reflection. It is thus the visual level that expresses the full extent of Elliot's mental health problems and of his unreliability as a narrator.

\section{Conclusion}

Stance, in its various realisations, is closely related to many of the aspects of fiction that are most central for pragmatics. It plays a crucial role in establishing narratorial voice and for characterisation. It can reveal the dynamics between different characters, which in turn is related to plot development. And it lends itself well to multimodal analysis, an area that is becoming more and more important in pragmatic approaches to fiction. Therefore, it is surprising that the systematic study of stance in fiction has not attracted a great deal of attention so far.

Research on stance in other domains can contribute tools and methods for the study of stance in fiction. Recent developments in research on stance in interpersonal interaction are particularly promising in this respect, but also the study of more local realisations of stance markers in narratorial voice and the speech of individual characters provides interesting avenues for further research. As far as multimodal realisations of stance are concerned, future research could benefit from bringing together linguistic approaches to stance taking with approaches from film and performance studies, which have a longer tradition of interpreting non-verbal aspects of acting and narration. All in all, stance in fiction is a promising area for future research. 


\section{Acknowledgments}

I thank Jonathan Culpeper, Carolina Fernandez-Quintanilla, Martin Mühlheim and the editors of this volume for valuable comments and suggestions on a draft version of this chapter. I would also like to acknowledge the financial support through the Forschungskredit of the University of Zurich (grant no. FK-14-074).

\section{References}

\section{Primary sources}

Austen, Jane

2003 Emma. Oxford, UK: Oxford University Press. First published [1816].

Dickens, Charles

2000 Great Expectations. London: Wordsworth Editions Limited. First published [1860-1861].

Eliot, George

1965 Middlemarch. London: Penguin Books. First published [1871-1872].

Eliot, George

1985 The Mill on the Floss. London: Penguin Books. First published [1880].

Hemingway, Ernest

1962 The short happy life of Francis Macomber. In: Ernest Hemingway (ed.), The First Forty-Nine Stories, 11-40. London: Jonathan Cape. First published [1936].

Mr. Robot. Episode 1: eps1.0_hellofriend.mov

2015 Dir. by Niels Arden Oplev. Screenplay by Sam Esmail. Anonymous Content and Universal Cable Productions.

Mr. Robot. Episode 8: eps1.7_wh1ter0se.m4v

2015 Dir. by Christoph Schrewe. Screenplay by Randolph Leon. Anonymous Content and Universal Cable Productions.

Secondary sources

Aikhenvald, Alexandra Y.

2004 Evidentiality. Oxford, UK: Oxford University Press.

Alba-Juez, Laura and Geoff Thompson

2014 The many faces and phases of evaluation. In: Geoff Thompson and Laura Alba-Juez (eds.), Evaluation in Context, 3-23. Amsterdam: John Benjamins.

Androutsopoulos, Jannis (ed.)

2012 Language and Society in Cinematic Discourse. Special Issue, Multilingua $31(2-3)$.

Bednarek, Monika

2006 Evaluation in Media Discourse: Analysis of a Newspaper Corpus. (Research in Corpus and Discourse.) London: Continuum.

Bednarek, Monika

2008 Emotion Talk across Corpora. Basingstoke, UK: Palgrave Macmillan. 
Bednarek, Monika

2010 The Language of Fictional Television: Drama and Identity. London: Continuum.

Biber, Douglas, Stig Johansson, Geoffrey Leech, Susan Conrad and Edward Finegan

1999 Longman Grammar of Spoken and Written English. London: Longman.

Bleichenbacher, Lukas

2008 Multilingualism in the Movies: Hollywood Characters and Their Language Choices. (Swiss Studies in English 135.) Tübingen: Francke.

Bordwell, David and Kristin Thompson

2004 Film Art. An Introduction, $7^{\text {th }}$ Ed. Boston, MA: McGraw-Hill.

Brown, Tom

2012 Breaking the Fourth Wall: Direct Address in the Cinema. Edinburgh: Edinburgh University Press.

Bubel, Claudia M.

2011 Relationship impression formation: How viewers know people on the screen are friends. In: Roberta Piazza, Monika Bednarek and Fabio Rossi (eds.), Telecinematic Discourse: Approaches to the Language of Films and Television Series, 225-247. Amsterdam: John Benjamins.

Bucholtz, Mary and Kira Hall

2005 Identity and interaction: A sociocultural linguistic approach. Discourse Studies 7(4-5): 585-614.

Burnard, Lou

2009 BNC User Reference Guide. http://www.natcorp.ox.ac.uk/docs/URG/BNCdes. html\#BNCcompo [accessed on November 3, 2015]

Channell, Joanna

2000 Corpus-based analysis of evaluative lexis. In: Susan Hunston and Geoff Thompson (eds.), Evaluation in Text: Authorial Stance and the Construction of Discourse, 38-56. Oxford, UK: Oxford University Press.

Conrad, Susan and Douglas Biber

2000 Adverbial marking of stance in speech and writing. In: Susan Hunston and Geoff Thompson (eds.), Evaluation in Text: Authorial Stance and the Construction of Discourse, 56-73. Oxford, UK: Oxford University Press.

Cortazzi, Martin and Lixian Jin

2000 Evaluating evaluation in narrative. In: Susan Hunston and Geoff Thompson (eds.), Evaluation in Text: Authorial Stance and the Construction of Discourse, 102-120. Oxford, UK: Oxford University Press.

Culpeper, Jonathan and Merja Kytö

2010 Early Modern English Dialogues: Spoken Interaction as Writing. Cambridge, UK: Cambridge University Press.

Davies, Bronwyn and Rom Harré

1990 Positioning: The discursive production of selves. Journal for the Theory of Social Behaviour 20(1): 43-63.

Davies, Mark

2012 Word Counts of the 2012 Version of the Corpus of Contemporary American English. http://corpus.byu.edu/coca/help/nwByGenre.asp [accessed on November 3, 2015] 
Du Bois, John W.

2007 The stance triangle. In: Robert Englebretson (ed.), Stancetaking in Discourse: Subjectivity, Evaluation, Interaction, 139-182. (Pragmatics \& Beyond New Series 164.) Amsterdam: John Benjamins.

Du Bois, John W. and Elise Kärkkäinen

2012 Taking a stance on emotion: Affect, sequence, and intersubjectivity in dialogic interaction. Text \& Talk 32(4): 433-451.

Englebretson, Robert

2007 Stancetaking in discourse. An introduction. In: Robert Englebretson (ed.), Stancetaking in Discourse: Subjectivity, Evaluation, Interaction, 1-25. (Pragmatics \& Beyond New Series 164.) Amsterdam: John Benjamins.

Escandell-Vidal, Victoria, Victoria Marrero Aguiar and Pilar Pérez Ocón

2014 Prosody, information structure and evaluation. In: Geoff Thompson and Laura Alba-Juez (eds.), Evaluation in Context, 153-177. Amsterdam: John Benjamins.

Estebas-Vilaplana, Eva

2014 The evaluation of intonation: Pitch range differences in English and in Spanish. In: Geoff Thompson and Laura Alba-Juez (eds.), Evaluation in Context, 179-194. Amsterdam: John Benjamins.

Faller, Martina T.

2002 Semantics and pragmatics of evidentials in Cuzco Quechua. Ph.D. dissertation, Stanford University. http://personalpages.manchester.ac.uk/staff/martina. t.faller/documents/Thesis-A4.pdf [accessed on December 1, 2015]

Fowler, Roger

1996 Linguistic Criticism, $2^{\text {nd }}$ Ed. Oxford, UK: Oxford University Press.

Gray, Bethany and Douglas Biber

2014 Stance markers. In: Karin Aijmer and Christoph Rühlemann (eds.), Corpus Pragmatics. A Handbook, 219-247. Cambridge, UK: Cambridge University Press.

Hayward, Susan

2006 Cinema Studies: The Key Concepts, $3^{\text {rd }}$ Ed. London: Routledge.

Hoey, Michael

2000 Persuasive rhetoric in linguistics: A stylistic study of some features of the language of Noam Chomsky. In: Susan Hunston and Geoff Thompson (eds.), Evaluation in Text: Authorial Stance and the Construction of Discourse, 28-37. Oxford, UK: Oxford University Press.

Hunston, Susan

2000 Evaluation and the planes of discourse: Status and value in persuasive texts. In: Susan Hunston and Geoff Thompson (eds.), Evaluation in Text: Authorial Stance and the Construction of Discourse, 176-207. Oxford, UK: Oxford University Press.

Hunston, Susan

2004 Counting the uncountable: Problems of identifying evaluation in a text and in a corpus. In: Alan Partington, John Morley and Louann Haarman (eds.), Corpora and Discourse, 157-188. Bern: Peter Lang. 
Hunston, Susan

2007 Using a corpus to investigate stance quantitatively and qualitatively. In: Robert Englebretson (ed.), Stancetaking in Discourse: Subjectivity, Evaluation, Interaction, 27-48. (Pragmatics \& Beyond New Series 164.) Amsterdam: John Benjamins.

Hunston, Susan

2011 Corpus Approaches to Evaluation: Phraseology and Evaluative Language. New York: Routledge.

Hunston, Susan and Geoff Thompson (eds.)

2000 Evaluation in Text: Authorial Stance and the Construction of Discourse. Oxford, UK: Oxford University Press.

Jaffe, Alexandra

2009 Introduction: The sociolinguistics of stance. In: Alexandra Jaffe (ed.), Stance: Sociolinguistic Perspectives, 3-28. Oxford, UK: Oxford University Press.

Kärkkäinen, Elise

2003 Epistemic Stance in English Conversation: A Description of Its Interactional Functions, with a Focus on I think. (Pragmatics \& Beyond New Series 115.) Amsterdam: John Benjamins.

Kärkkäinen, Elise

2006 Stance taking in conversation: From subjectivity to intersubjectivity. Text \& Talk 26(6): 699-731.

Keisanen, Tiina and Elise Kärkkäinen

2014 Stance. In: Klaus P. Schneider and Anne Barron (eds.), Pragmatics of Discourse, 295-322. (Handbooks of Pragmatics 3.) Berlin: Mouton de Gruyter.

Lambrou, Marina

2014 Stylistics, conversation analysis and the cooperative principle. In: Michael Burke (ed.), The Routledge Handbook of Stylistics, 136-154. London: Routledge.

Leech, Geoffrey and Mick Short

2007 Style in Fiction: A Linguistic Introduction to English Fictional Prose, $2^{\text {nd }}$ Ed. (English Language Series 13.) Harlow, UK: Pearson Longman.

Maley, Alan

1999 Surviving the 20th century. English Teaching Professional 10: 3-7.

Martin, James R.

2000 Beyond exchange: Appraisal systems in English. In: Susan Hunston and Geoff Thompson (eds.), Evaluation in Text: Authorial Stance and the Construction of Discourse, 142-175. Oxford, UK: Oxford University Press.

Martin, James R. and Peter R. R. White

2005 The Language of Evaluation: Appraisal in English. Basingstoke, UK: Palgrave Macmillan.

Müller, Sabine

2014 Embodied cognition and camera mobility in F. W. Murnau's The Last Laugh and Fritz Lang's M. Paragraph 37(1): 32-46.

Naremore, James

1988 Acting in the Cinema. Berkeley, CA: University of California Press.

Neary, Clara

2014 Stylistics, point of view and modality. In: Michael Burke (ed.), The Routledge Handbook of Stylistics, 175-190. London: Routledge. 
Niederhoff, Burkhard

2014 Perspective - point of view. In: Peter Hühn, John Pier, Wolf Schmid and Jörg Schönert (eds.), Handbook of Narratology, $2^{\text {nd }}$ Ed., 692-705. Berlin: Mouton de Gruyter.

Nørgaard, Nina

2014 Multimodality and stylistics. In: Michael Burke (ed.), The Routledge Handbook of Stylistics, 471-484. London: Routledge.

Piazza, Roberta, Monika Bednarek and Fabio Rossi (eds.)

2011 Telecinematic Discourse: Approaches to the Language of Films and Television Series. Amsterdam: John Benjamins.

Planchenault, Gaëlle

2015 Voices in the Media: Performing French Linguistic Otherness. New York: Bloomsbury.

Quaglio, Paulo

2009 Television Dialogue: The Sitcom Friends vs. Natural Conversation. Amsterdam: John Benjamins.

Rimmon-Kenan, Shlomith

2002 Narrative Fiction: Contemporary Poetics, $2^{\text {nd }}$ Ed. London: Routledge.

Simpson, Paul

1993 Language, Ideology and Point of View. London: Routledge.

Stivers, Tanya

2008 Stance, alignment, and affiliation during storytelling: When nodding is a token of affiliation. Research on Language and Social Interaction 41(1): 31-57.

Tagliamonte, Sali and Chris Roberts

2005 So weird; so cool; so innovative: The use of intensifiers in the television series Friends. American Speech 80(3): 280-300.

Thompson, Geoff and Susan Hunston

2000 Evaluation: An Introduction. In: Susan Hunston and Geoff Thompson (eds.), Evaluation in Text: Authorial Stance and the Construction of Discourse, 1-27. Oxford, UK: Oxford University Press.

Thompson, Geoff and Jianglin Zhou

2000 Evaluation and organization in text: The structuring role of evaluative disjuncts. In: Susan Hunston and Geoff Thompson (eds.), Evaluation in Text: Authorial Stance and the Construction of Discourse, 121-141. Oxford, UK:

Toolan, Michael J. Oxford University Press.

1988 Narrative. A Critical Linguistic Introduction. London: Routledge. 